\title{
Investigation of the anti-cancer and apoptotic properties of aqueous extract from fermented African locust bean seeds
}

\author{
1,*Ayo-Lawal, R.A., ${ }^{2}$ Sibuyi, N.R., ${ }^{3}$ Ekpo, O., ${ }^{2}$ Meyer, M. and ${ }^{4}$ Osoniyi, O. \\ ${ }^{I}$ National Centre for Technology Management (NACETEM), Obafemi Awolowo University, Ile-Ife, Osun \\ State, Nigeria \\ ${ }^{2}$ Department of Science and Technology/Mintek Nanotechnology Innovation Centre, Biolabels Unit, \\ Department of Biotechnology, University of the Western Cape, Life Sciences Building, Private Bag Box \\ X17, Bellville, Cape Town 7535, South Africa \\ ${ }^{3}$ Department of Medical Bioscience, University of the Western Cape, Life Sciences Building, Bellville, Cape \\ Town, South Africa \\ ${ }^{4}$ Department of Biochemistry and Molecular Biology, Obafemi Awolowo University, Ile - Ife, Osun State, \\ Nigeria
}

\author{
Article history: \\ Received: 23 June 2020 \\ Received in revised form: 15 \\ August 2020 \\ Accepted: 27 September 2020 \\ Available Online: 5 \\ December 2020
}

\section{Keywords:}

Fermented African locust

bean seeds,

Cytotoxicity,

Apoptotic,

Fermented Parkia biglobosa,

Anti-cancer,

DNA fragmentation

DOI:

https://doi.org/10.26656/fr.2017.5(1).295

\begin{abstract}
Some fermented foods are reported to possess anti-cancer properties. Fermented African locust bean seeds is a condiment prepared from fermentation of Parkia biglobosa. It has been reportedly functional for various medicinal activities but not anti-cancer. The cytotoxic and apoptosis-inducing properties of the aqueous extract of the condiment were investigated in human cancer - hepatocellular (Hep-G2) and cervical (HeLa) and noncancer cell lines. Cytotoxicity was evaluated using the 3-(4,5-dimethylthiazol-2-yl)-2,5diphenyl tetrazolium bromide (MTT) and clonogenic cell survival assays. Apoptotic cell death and DNA fragmentation were also investigated. The results revealed cytotoxicity to both cell lines in a dose-dependent manner $(P<0.05)$ and selective activities between cancer and non-cancer cells. The $\mathrm{IC}_{50}$ values were 1.3 and $0.5 \mathrm{mg} / \mathrm{mL}$ for Hep-G2 and HeLa cells respectively. Furthermore, the extract induced apoptotic cell death in only Hep -G2 (73.03 \pm 0.73$)$ cells. The morphologic photomicrographs correlated well with other findings, indicating the cell-specific cytotoxicity of the condiment.
\end{abstract}

\section{Introduction}

Existing scientific reports reveal that many naturally fermented foods and beverages contain both functional and non-functional microorganisms (Tamang et al., 2016), with the ability to modulate specific target functions in the body leading to the well-being and health of the consumers. Some fermented foods and beverages have been reported to be useful in cancer prevention and treatment including kefir (Otes et al., 2003; Wang et al., 2009), sauerkraut a fermented vegetable in Germany (Kris-Etherton et al., 2002), kimchi (Park et al., 2014) and many others.

African locust bean (Parkia biglobosa) species represents one of the indigenous medicinal plants available across West and Central Africa. The fermented African locust beans (Figure 1) is a soup/stew condiment prepared by natural fermentation of $P$. biglobosa seeds. The condiment is well researched and reported to possess diverse nutritional and medicinal properties. This condiment can be eaten directly but it is mainly used as a spice in the preparation of various delicious meals. The fermented seeds are given various names depending on location, these include dawadawa in Ghana and northern Nigeria; iru in Benin Republic and southern Nigeria; and soumbala in Burkina Faso. Various extracts from the fermented seeds of $P$. biglobosa have been studied for their usefulness in the prevention, treatment, and management of various disease conditions (using various models) including diabetes mellitus (Odetola et al., 2006), hypertension (Ognatan et al., 2011), antioxidant and hypolipidaemic effect (Ayo-Lawal et al., 2014). There is however no study in the literature that has reported the cytotoxic activity of fermented P. biglobosa (FPB) seeds. The present study was done to investigate the cytotoxic and apoptotic effects of the aqueous extract of FPB seeds on HeLa and Hep-G2 cells. 


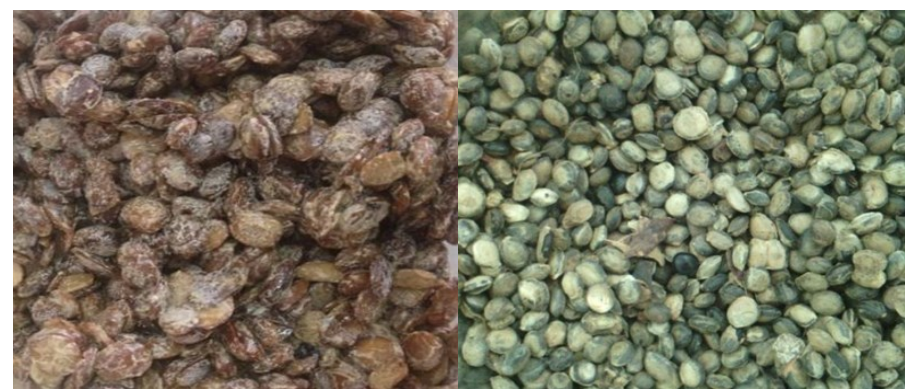

Figure 1. Fermented African locust bean seeds (A) prepared from raw P. biglobosa seeds (B)

\section{Materials and methods}

\subsection{Preparation of the aqueous extract from FPB seeds}

Indigenously prepared (Ayo-Lawal et al., 2016) FPB seeds were obtained from a commercial producer and smoothened to a paste using a mortar and pestle in the Biochemistry laboratory of the Obafemi Awolowo University, Osun State, Nigeria. The aqueous extract was obtained by soaking the paste in distilled water for $48 \mathrm{hrs}$ and the supernatant was collected. The residue was thereafter squeezed in a mesh filter cloth to collect all the filtrate which was then freeze-dried to obtain a dried marc.

\subsection{Cell culture and growth}

Hepatocellular (Hep-G2) and cervical (HeLa) cancer cell lines were obtained from the Department of Biotechnology, University of the Western Cape, South Africa. These cells were grown in complete Dulbecco's Modified Eagle Medium (DMEM Life Technologies, USA), supplemented with $10 \%$ foetal bovine serum (FBS) and $1 \%$ penicillin-streptomycin cocktail $(100 \mathrm{U} /$ $\mathrm{mL}$ penicillin and $100 \mu \mathrm{g} / \mathrm{mL}$ streptomycin, Lonza, USA) in a humidified incubator - Labotech, South Africa $\left(5 \% \mathrm{CO}_{2}\right.$ in air at $\left.37^{\circ} \mathrm{C}\right)$.

\subsection{Assessment of the cytotoxicity of the aqueous FPB seeds extract}

Hep-G2 and HeLa cells were seeded in 96-well plates at $8 \times 10^{4} / \mathrm{mL}$ and $5 \times 10^{4} / \mathrm{mL}$ respectively and incubated for $24 \mathrm{hrs}$ under standard conditions to attach. The cells were thereafter incubated with aqueous FPB seeds extract at various concentrations $(0.5-2.5 \mathrm{mg} / \mathrm{mL})$ for 24,48 and 72 hrs respectively. Cytotoxicity was assessed using the 3-(4,5-dimethylthiazol-2-yl)-2,5diphenyl tetrazolium bromide (MTT, St. Louis, MO, USA) assay. Here, $10 \mu \mathrm{L}$ of $5 \mathrm{mg} / \mathrm{mL}$ MTT (dissolved in phosphate buffered saline (PBS)) was added to each well of a 96-well plate containing treated cells, and then incubated at $37^{\circ} \mathrm{C}$ for $4 \mathrm{hrs}$. The formazan crystals formed were thereafter solubilized by adding $100 \mu \mathrm{L}$ DMSO and absorbance read at $570 \mathrm{~nm}$ using the POLAR Star Omega plate reader (BMG Labtech, Germany).
Experiments were performed in triplicates and the halfmaximal cytotoxic concentration $\left(\mathrm{IC}_{50}\right)$ was calculated from log dose-response curves using the Graph Pad Prism software for Windows. Cell viability (percentage of control) (Badmus et al., 2015) was calculated as:

(Average absorbance of treated cells/Average absorbance of control cells) x 100

\subsection{Investigation of cell morphology}

Morphological changes in HeLa and Hep-G2 cells were observed after treatment with the aqueous FPB extract for $24 \mathrm{hrs}$. Briefly, HeLa (5x10 $/$ well) and HepG2 $\left(8 \times 10^{3} /\right.$ well $)$ cells were seeded into a 24 -well plate (in triplicates) and incubated for $24 \mathrm{hrs}$ to attach. Thereafter, HeLa and Hep-G2 cells were treated with the previously determined $\mathrm{IC}_{50}$ concentrations of 0.5 and 1.3 $\mathrm{mg} / \mathrm{mL}$ respectively for $24 \mathrm{hrs}$, and washed once with PBS, cells morphologies were viewed under the ZEISS Primo Vert inverted microscope (ZEISS, Germany) and images captured at x200 magnification.

\subsection{Assessment of cell survival - the clonogenic assay}

Reproductive cell death was assessed in HeLa and Hep-G2 cells following treatment with the aqueous of FPB extract for $24 \mathrm{hrs}$ using a previously reported protocol (Badmus et al., 2015). Briefly, HeLa (3.28 x $\left.10^{5}\right)$ and Hep-G2 $\left(5.25 \times 10^{5}\right)$ cells in $5 \mathrm{~mL}$ were seeded in $60 \mathrm{~mm}$ dishes and incubated for $24 \mathrm{hrs}$. Thereafter, the cells were treated with the same concentration of the extract as above, for $24 \mathrm{hrs}$ while the untreated cells were used as control. Treated and untreated cells were trypsinized and further seeded at $1 \times 10^{3}$ into a $35-\mathrm{mm}$ dish and cultured again depending on proliferation rate (HeLa for 5 days; Hep-G2 for 7 days). During the culturing stage of the experiment, media was changed daily, and cells were thereafter fixed with $750 \mu \mathrm{L}$ of the mixture of methanol: acetic acid (3:1) for 15 mins at room temperature. The cells were then stained with crystal violet for 10 mins at room temperature and photomicrographs of the air-dried dishes were captured using the ZEISS Primo Vert inverted microscope. Experiments were performed in triplicates and the total number of colonies on each dish was counted using a colony counter (TT 201 Techmel and Techmel, USA).

\subsection{Flow cytometric analysis of apoptosis}

The flow cytometer based APOPercentage ${ }^{\mathrm{TM}}$ assay was utilized to quantify apoptosis in treated and untreated cells (Meyer et al., 2008). Briefly, HeLa and Hep-G2 cells were seeded at a density of $1 \times 10^{5}$ into 24 well plates and allowed to attach for $24 \mathrm{hrs}$ under standard incubation conditions. Thereafter, three 
different extract concentrations representing values < $\mathrm{IC}_{50}, \mathrm{IC}_{50}$, and $>\mathrm{IC}_{50}$ were used to treat Hep-G2 $(0.8$, $1.3,2.0 \mathrm{mg} / \mathrm{mL})$ and $\mathrm{HeLa}(0.3,0.6,0.9 \mathrm{mg} / \mathrm{mL})$ cells. Positive control cells were treated with 6\% DMSO for 24 hrs followed by staining with the APOPercentage ${ }^{\mathrm{TM}}$ dye dissolved in PBS (1:160) and analysis using the BD Accuri ${ }^{\mathrm{TM}}$ C6 flow cytometer (BD Biosciences, Belgium).

\subsection{DNA fragmentation analysis of apoptosis}

Qualitative analysis and confirmation of apoptotic induction in Hep-G2 and HeLa cells were done by investigating DNA fragmentation following treatment with the extract for $24 \mathrm{hrs}$ in $1.5 \%$ agarose gel electrophoresis. Briefly, HeLa (100,000/well) and HepG2 (100,000/well) cells in $3 \mathrm{~mL}$ complete DMEM medium were incubated under standard conditions for 24 hrs and thereafter separately treated with $0.6 \mathrm{mg} / \mathrm{mL}$ and $1.3 \mathrm{mg} / \mathrm{mL}$ extract concentrations respectively, being the respective $\mathrm{IC}_{50}$ values. The control cells were on the other hand not exposed to any extract treatment (negative control). Cells were prepared as previously described by Bossú (1999) and the DNA marker (Fermentas Fast Ruler $^{\mathrm{TM}}$ ) was used as a reference. The electrophoresis analysis was run in standard TBE buffer (voltage 90 for 30 mins) and used for the migration of molecules in the samples based on size and electrical charge. Fragmented DNA movements were visualized by placing the gel on an ultraviolet transilluminator and photographing. Bands were compared with those of the DNA marker.

\subsection{Statistical analysis}

The GraphPad Prism software version 5.0 for Windows (GraphPad Software, Inc., California) was used for estimating $\mathrm{IC}_{50}$ via the linear regression equation and for plotting the graphs. Data obtained was analysed and expressed as Mean \pm Standard Error of Mean and one-way analysis of variance (ANOVA) followed by Dunnet multiple comparison post-hoc test was used to determine statistical significance $(p<0.05)$ across groups.

\section{Results}

\subsection{Cytotoxicity of aqueous FPB seeds extract to cancer cells}

The aqueous extract of FPB seeds was found to be significantly $(\mathrm{P}<0.05)$ cytotoxic to both Hep-G2 (Figure 2) and $\mathrm{HeLa}$ (Figure 3) cells in a concentrationdependent manner. The $\mathrm{IC}_{50}$ concentrations at $24 \mathrm{hrs}$ were approximately $1.3 \mathrm{mg} / \mathrm{mL}$ and $0.6 \mathrm{mg} / \mathrm{mL}$ for HepG2 and HeLa cells respectively, suggesting that HeLa cells were more susceptible to the cytotoxic activity of the extract. Furthermore, the cytotoxic effects of the extract to cells was found to increase with increased incubation time as evidenced by the progressive decrease in $\mathrm{IC}_{50}$ values with time (Table 1).

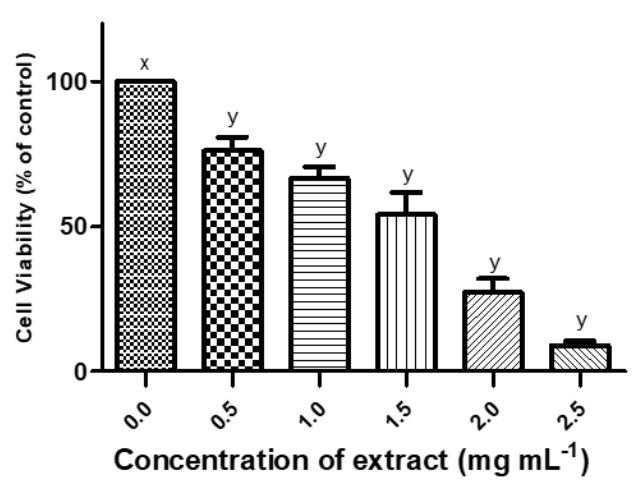

Figure 2. Cytotoxicity of aqueous fermented P. biglobosa seeds on Hep-G2.

$*_{y}$ is significantly different from $\mathrm{x}(\mathrm{P}<0.05)$ in each case.

Hep-G2 cells were treated with increasing concentrations of fermented $P$. biglobosa extract for $24 \mathrm{hrs}$; cell cytotoxicity was assessed using MTT assay

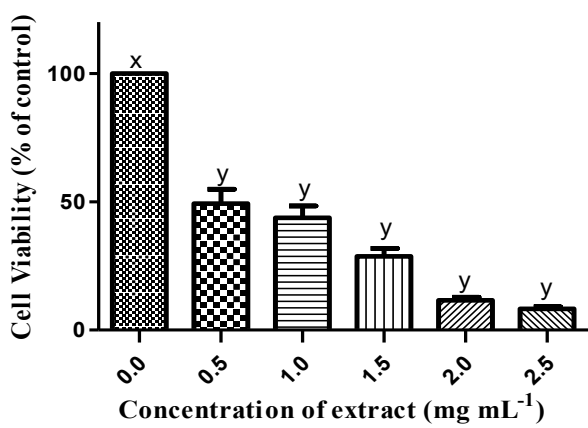

Figure 3. Cytotoxicity of aqueous fermented P. biglobosa seeds on HeLa cells. *

$\mathrm{y}$ is significantly different from $\mathrm{x}(\mathrm{P}<0.05)$ in each case.

HeLa cells were treated with increasing concentrations of fermented $P$. biglobosa extract for $24 \mathrm{hrs}$; cell cytotoxicity was assessed using MTT assay

Table 1. Incubation time versus half maximal inhibitory concentrations $\left(\mathrm{IC}_{50}\right)(\mathrm{mg} / \mathrm{mL})$ of aqueous fermented $P$. biglobosa extract in different cell lines

\begin{tabular}{ccc}
\hline $\begin{array}{c}\text { Incubation } \\
\text { Time (hrs) }\end{array}$ & $\begin{array}{c}\text { Hep-G2 (Human } \\
\text { Hepatocellular Cells) }\end{array}$ & $\begin{array}{c}\text { HeLa (Human } \\
\text { Cervical Cells) }\end{array}$ \\
\hline 24 & 1.3 & 0.6 \\
48 & 1.2 & 0.4 \\
72 & 0.8 & 0.3 \\
\hline
\end{tabular}

3.2 Morphological alterations in Hep-G2 and HeLa cells following treatment with aqueous FPB extract

The Hep-G2 and HeLa cells not treated with the aqueous extract of FPB maintained their original structure and conformation with increased proliferation, reaching up to $90 \%$ confluence at the end of the experiment and remaining attached to the bottom of the plates. In contrast, the extract-treated Hep-G2 and HeLa cells had less cell volume (seeding density was equal in both treated and untreated cells prior to treatment). Cells 
in the treated dishes appeared to have lost cell-cell and cell-plate contacts and remained floated in the medium, with perturbed morphology. Dead cells were also captured in both extract-treated dishes (Figure 4).

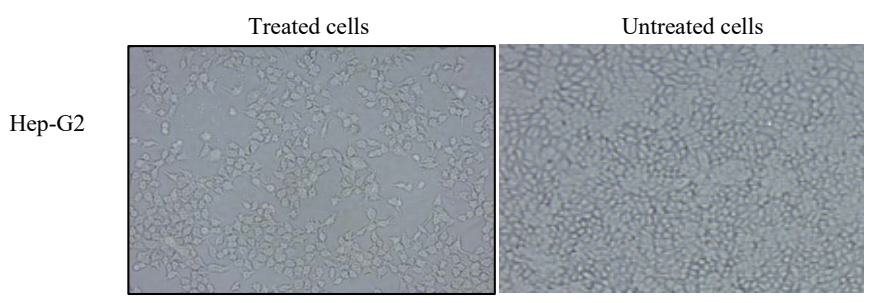

HeLa

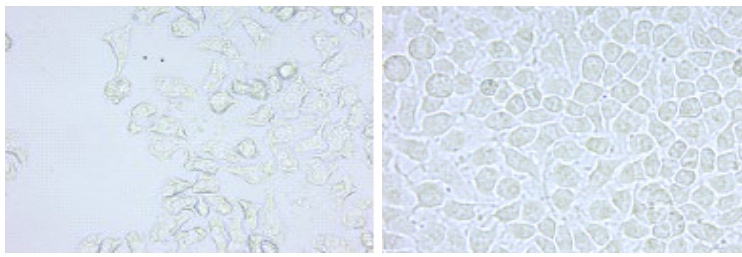

Figure 4. Morphological alterations in Hep-G2 and HeLa Cells following $24 \mathrm{hrs}$ treatment with aqueous FPB extract.

Morphological alteration in Hep-G2 and HeLa cells following treatment with aqueous extract of fermented African locust bean seeds. Hep-G2 and HeLa cells were treated with the aqueous extract for $24 \mathrm{hrs}$. Cells were washed, morphology viewed and the images were captured by ZEISS Primo Vert inverted microscope at x200 magnification

\subsection{Clonogenic effects of the aqueous fermented Parkia biglobosa seeds extract on Hep-G2 and HeLa cells}

There was a significant reduction in the number of colonies formed in both Hep-G2 and HeLa cells treated with the aqueous FPB extract compared with the untreated cells (Figure 5). The untreated dish containing Hep-G2 cells had $556.66 \pm 24$ colonies, while the treated Hep-G2 cells had only $71.33 \pm 4$ colonies. Similarly, the number of colonies in the untreated HeLa dish was $832.66 \pm 23$, while the treated cells had only $115.33 \pm 6$ colonies (Figure 5).

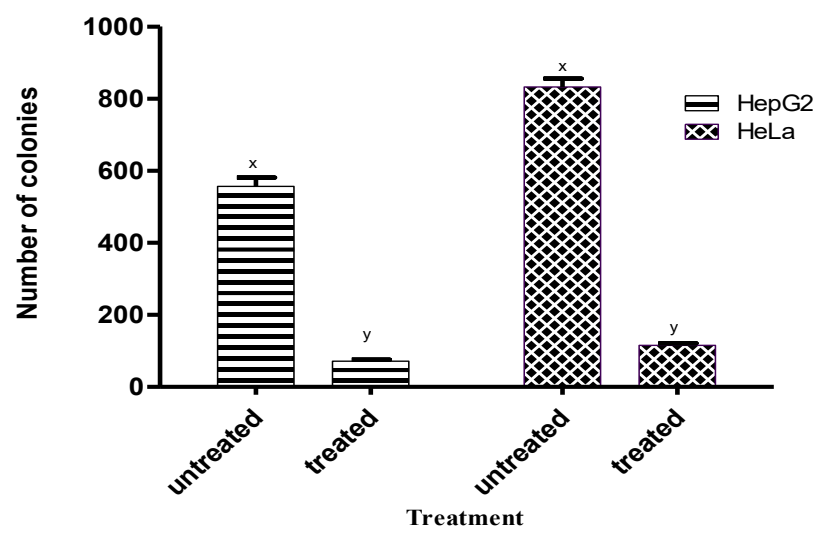

Figure 5. Clonogenic effects of aqueous fermented $P$. biglobosa seeds extract on Hep-G2 and HeLa Cells.

Following treatment of HeLa and Hep-G2 cells with aqueous FPB extract, cells were fixed and processed. Cell colonies were counted using a colony counter (TT 201 Techmel and Techmel, USA).
3.4 Induction of apoptosis in Hep-G2 and HeLa cells following treatment with the aqueous extract of FPB seeds

In this study, the aqueous extract of FPB seeds was found to induce concentration-dependent apoptosis in Hep-G2 (Figure 6) and not in HeLa cells (Figure 7). Three concentrations representing $<\mathrm{IC}_{50}, \mathrm{IC}_{50}$ and $>\mathrm{IC}_{50}$ were used in each case, and experiments were performed in triplicates. The average numbers of apoptotic cells measured in the wells treated with the $\mathrm{IC}_{50}$ extract concentrations were $73.03 \pm 0.73$ and $35.10 \pm 3.28$ for the Hep-G2 and HeLa cells respectively.

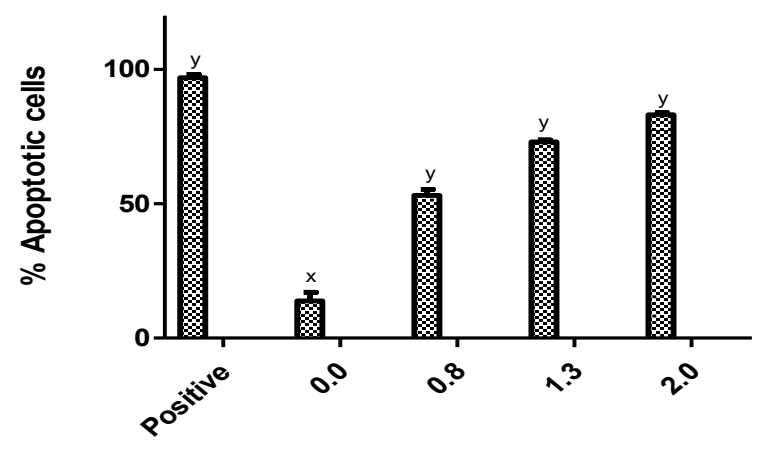

Concentration of extract $\left(\mathrm{mg} \mathrm{mL}^{-1}\right)$

Figure 6. Induction of apoptosis in Hep-G2 cells following treatment with aqueous FPB seeds. Positive well contained $6 \%$ DMSO.

$*_{\mathrm{y}}$ is significantly different from negative control $(\mathrm{x})$ at $\mathrm{P}<0.05$.

Investigation of apoptotic induction by APOPercentage ${ }^{\mathrm{TM}}$ assay. Hep-G2 cells were treated for $24 \mathrm{hrs}$ with three increasing concentrations of aqueous extract of fermented $P$. biglobosa seeds. The cells were stained with the APOPercentage ${ }^{\mathrm{TM}}$ dye and evaluated using a flow cytometer. Each bar chat represents the means \pm SEM of three independent experiments.

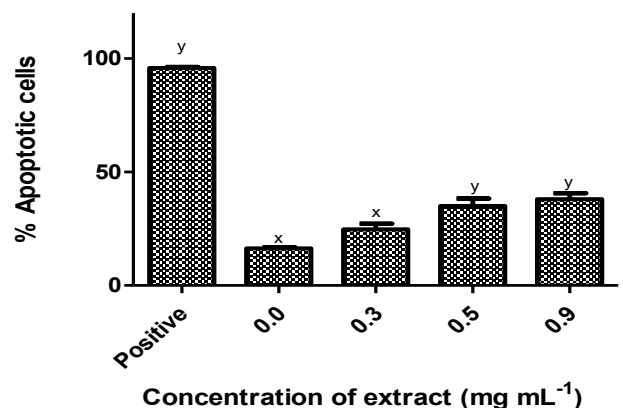

Figure 7. Apoptotic induction in HeLa cells following treatment with increasing concentrations of aqueous FPB seeds extract. Positive well contained 6\% DMSO.

$*_{\mathrm{x}}$ is not significantly different from negative control $(0.0)$ while y is significantly different at $\mathrm{P}<0.05$.

Investigation of apoptotic induction by APOPercentage ${ }^{\mathrm{TM}}$ assay. HeLa cells were treated for $24 \mathrm{hrs}$ with three increasing concentrations of aqueous extract of fermented P. biglobosa seeds. The cells were stained with the APOPercentage ${ }^{\mathrm{TM}}$ dye and evaluated using a flow cytometer. Each bar chat represents the means \pm SEM of three independent experiments. 
3.5 Induction of DNA fragmentation in Hep-G2 and HeLa cells following treatment with the aqueous extract of FPB seeds

The electrophoretic wells (in both gels) loaded with samples from the untreated cells clearly indicated the absence of DNA fragments; neither smears nor bands. On the other hand, a band corresponding to about 250 base pair or less on the DNA marker was seen for the wells loaded with treated Hep-G2 cells (Figure 8A). A weaker band was seen in the wells loaded with treated HeLa cells, indicative of some DNA fragments of similar size (Figure 8B) which is suggestive of apoptotic induction in both cells.

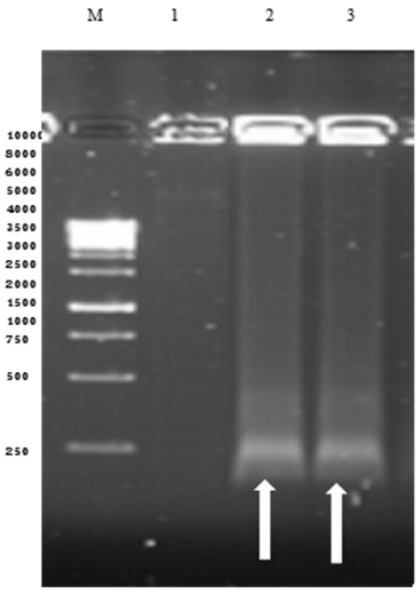

A

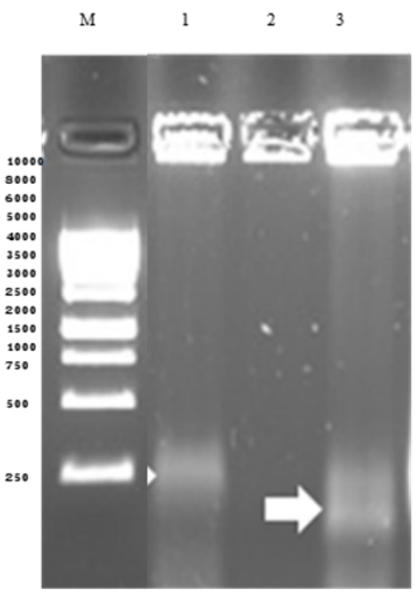

B
Figure 8. Qualitative analysis of DNA fragmentation by agarose gel electrophoresis in treated and untreated Hep G2 (A) and HeLa (B) cells. Hep-G2 (M - DNA marker, 1 Untreated sample (control), 2,3, - Aqueous FPB extracttreated sample. HeLa (M - DNA marker, 2 - Untreated sample (control), 1,3, - Aqueous FPB extract-treated sample

\section{Discussion}

Fermented indigenous foods and associated microbiota have been associated with various health benefits for many years. These effects could be achieved via various mechanisms including the activation of the immune system, mitigation of carcinogenicity, and induction of apoptosis (Ghosh et al., 2019) among others. Cytotoxic compounds which selectively initiate apoptosis in cancer cells and hence slow down proliferation are considered potential candidates for cancer therapy (Xiao et al., 2007). In this study, the aqueous extract of the seeds of fermented P. biglobosa, (which is the readily-edible state of the condiment) was found to have significant cytotoxic effects on both HepG2 and HeLa cells, with the latter being more susceptible. Microscopic examination showed distortions in the morphology of Hep-G2 and HeLa cells which correlated with the observed cytotoxic effects. In addition, the clonogenic assay demonstrated that the extract exerted a lasting cytotoxic effect on the Hep-G2 and HeLa cells, thus inhibiting the ability of the cells to reproduce and form colonies compared with the untreated cells.

Potential health benefits of many fermented foods have been attributed to the biologically active peptides, vitamins, and other compounds produced by the bacteria responsible for the fermentation process (Sanlier et al., 2010). In this study, the observed cytotoxic activities of FPB could have been caused by the bioactive peptides in the extract. Our previous unpublished data showed that the most abundant prevailing organisms in the FPB extract used in this study were the Bacillus spp, (especially B. subtilis). This finding is in agreement with previous studies by Odunfa (1981) who reported that members of the Bacillus spp. and Staphylococcus spp. as the prevailing organisms involved in the production of FPB. In addition, Odunfa and Oyewole (1986), found that all Bacillus species isolated from FPB were proteolytic and only $97.3 \%$ were lipolytic. Since protein is the major component of most fermented legumes such as P. biglobosa, Bacillus species serves to break down the protein into peptides and amino acids (Tamang and Nikkuni, 1996; Isu and Njoku, 1997). In addition, the fermentation of legume-based food substances is known to increase the content of phenolic compounds in the seeds which increases their nutritional value.

Apoptosis remains the major cell death pathway for removing unwanted and harmful cells in a non-disruptive manner. Abnormal evasion from apoptosis is typical of cancer cells, so the ability of a compound or an extract to induce apoptosis in cancer cells could be a promising lead to the anti-cancer potential of such a compound (Frankfurt and Krishnan, 2003). Here, the induction of apoptosis in $\mathrm{HeLa}$ and Hep-G2 cells was quantified following treatment with the aqueous extract of FPB extract for $24 \mathrm{hrs}$ using the flow cytometer-based APOPercentage ${ }^{\mathrm{TM}}$ assay. The dye was only taken up by apoptotic-committed cells, recognized by phosphatidyl serine externalization (Meyer et al., 2008) compared to DMSO which is also an apoptosis-inducing agent (Banič et al., 2011). Significant activity was obtained in the Hep -G2 cells, unlike in the HeLa cells. This could suggest that different pathways might be involved in the cytotoxic activity of the extract in the two cancer cells investigated.

The detection of DNA fragmentation is currently one of the most frequently used techniques for highlighting apoptotic cells in tissues. One of the biochemical hallmarks of apoptosis is the degradation of DNA by endogenous dehydrogenases, which cut the internucleosomal regions into DNA fragments of $\sim 200$ 
base pairs (Arends, et al., 1990; Compton, 1992). The electrophoretic gel obtained in this study attested to the presence of DNA fragments corresponding to about 200 base pairs, indicative of apoptosis in both Hep-G2 and HeLa cells.

Two plausible indications emanated from the findings from this study; either HeLa cells could have been killed before the analysis, hence the dye could not bind to dead cells, or the assay is more applicable to cells that undergo apoptosis via the intrinsic pathway. Hence, if the observed cell death occurred via the extrinsic pathway, then the APOPercentage ${ }^{\mathrm{TM}}$ assay could not have demonstrated such cell death.

The anti-cancer activities of some fermented indigenous foods and associated microbiota have been well reported (Watanabe, 2013; Kwak et al., 2014; Park et al., 2014); and the induction of apoptotic pathways was suggested to be one of the ways by which fermented foods exert their anti-cancer effects. In this study, the aqueous extract from fermented African locust beans was found to significantly induce apoptosis in Hep-G2 cells. In another report, Kefir, a drink produced by milk fermentation and its cell free extract, was reported to exert its anti-carcinogenic effects via the induction of apoptotic mechanisms (Pẽnas et al., 2017), as well as anti-proliferative effect (Ghoneum and Gimzewski, 2014) on cancer cells. Kefir was also reported to be cytotoxic and induced apoptosis in HT-29 and Caco-2 colorectal cancer cells (Khoury et al., 2014; Maalouf et al., 2011).

\section{Conclusion}

The results obtained from this study further corroborate available information on the nutritional and medicinal values of fermented P. biglobosa seeds. Furthermore, the results indicate that the aqueous extract of fermented P. biglobosa seeds was significantly cytotoxic to both human hepatocellular and cervical cancer cells and induced cell death in the cells via apoptosis. This was the first attempt to investigate the effects of any extract from this well-known Nigerian food condiment on cancer cells. The results obtained provide a promising lead for further investigation, isolation, characterisation and the potential development of an anti-cancer nutraceutical from the condiment.

\section{Conflict of interest}

The authors declare that there is no conflict of interest regarding the publication of this manuscript.

\section{Acknowledgement}

The corresponding author expresses gratitude to the African-German Network of Excellence in Science (AGNES) for the intra-Africa mobility grant awarded her and for funding part of this study. The authors acknowledge the contributions and kind assistance of Dr Sylvester Omoruyi and Dr Adaze Enogieru during the bench work.

\section{References}

Arends, M.J., Morris, R.G. and Wyllie, A.H. (1990). Apoptosis: the role of the endonuclease. The American Journal of Pathology, 136(3), 593-608.

Ayo-Lawal R.A., Osoniyi, R.O., Rivera G. and Elufisan, T.O. (2016). Fermented Condiments from Melon (Citrullus vulgaris) and African Locust Bean (Parkia biglobosa) Seeds - A Review. Nigerian Food Journal, 34(2), 94 - 104.

Ayo-Lawal, R.A., Osoniyi, O., Famurewa, A.J. and Lawal, O.A. (2014). Evaluation of antioxidant and hypolipidaemic effects of fermented Parkia biglobosa (Jacq) seeds in tyloxapol-induced hyperlipidaemic rats. African Journal of Food Science, 8(5), 225-232. https://doi.org/10.5897/ AJFS2013.1124

Badmus, J.A., Ekpo, O.E., Hussein, A.A., Meyer, M. and Hiss, D.C. (2015). Antiproliferative and apoptosis induction potential of the methanolic leaf extract of Holarrhena floribunda (G. Don). Evidence-Based Complementary and Alternative Medicine, 2015, 756482. https://doi.org/10.1155/2015/756482

Banič, B., Nipič, D. Šupu, D. and Milisav, I. (2011). DMSO modulates the pathway of apoptosis triggering. Cellular and Molecular Biology Letters, 16(2), 328-341. https://doi.org/10.2478/s11658-0110007-y

Bossú, P. (1999). Qualitative analysis of DNA fragmentation by agarose gel electrophoresis. In Cossarizza, A. and Boraschi, D. (Eds.) Apoptosis: A laboratory Manual of Experimental Methods. Purdue cytometry CD-ROM volume 4. Retrieved on February 19, 2017 from Purdue University website: http://www.cyto.purdue.edu/archive/flowcyt/ research/cytotech/apopto/data/chap4.htm.

Compton, M.M. (1992). A biochemical hallmark of apoptosis: internucleosomal degradation of the genome. Cancer and Metastasis Review, 11, 105119. https://doi.org/10.1007/BF00048058

Ghoneum, M. and Gimzewski, J. (2014). Apoptotic effect of a novel kefir product, PFT, on multidrugresistant myeloid leukemia cells via a holepiercing mechanism. International Journal of 
Oncology, 44, 830-837. https://doi.org/10.3892/ ijo.2014.2258

Ghosh, T., Beniwal, A. Semwal, A. and Navani, N.K. (2019). Mechanistic Insights into probiotic properties of lactic acid bacteria associated with ethnic fermented dairy products. Frontiers in Microbiology, 10, 502 https://doi.org/10.3389/ fmicb.2019.00502

Isu, N.R. and Njoku, H.O. (1997). An evaluation of the microflora associated with fermented African oil bean (Pentaclethra macrophylla Bentham) seed during ugba production. Plant Food for Human Nutrition, 51, 145-157. https://doi.org/10.1023/ A: 1007906413195

Khoury, N., El-Hayek, S., Tarras, O., 1-Sabban, M. ElSibai, M. and Rizk, S. (2014). Kefir exhibits antiproliferative and proapoptotic effects on colon adenocarcinoma cells with no significant effects on cell migration and invasion. International Journal of Oncology, 45, 2117-2127. https://doi.org/10.3892/ ijo.2014.2635

Kris-Etherton, P.M., Hecker, K.D., Bonanome, A., Coval, S.M., Binkoski, A.E. and Hilpert, K.F. (2002). Bioactive compounds in foods: their role in the prevention of cardiovascular disease and cancer. The American Journal of Medicine, 113(9, Suppl. 2), 71-88. https://doi.org/10.1016/S0002-9343(01) 00995-0

Kwak, S.H., Cho, Y.M., Noh, G.M and Om, A.S. (2014). Cancer preventive potential of Kimchi lactic acid bacteria (Weissella cibaria, Lactobacillus plantarum). Journal of Cancer Prevention, 19(4), 253-258. https://doi.org/10.15430/ JCP.2014.19.4.253

Maalouf, K., Baydoun, E. and Rizk, S. (2011). Kefir induces cell-cycle arrest and apoptosis in HTLVInegative malignant T-lymphocytes. Cancer Management and Research, 3, 39-47. https:// doi.org/10.2147/CMAR.S15109

Meyer, M., Essack, M., Kanyanda, S. and Rees, J.G. (2008). A low-cost flow cytometric assay for the detection and quantification of apoptosis using an anionic halogenated fluorescein dye. Biotechniques, 45, 317-320. https://doi.org/10.2144/000112908

Odetola, A.A., Akinloye, O., Egunjobi, C., Adekunle, W.A. and Ayoola, A.O. (2006). Possible antidiabetic and antihyperlipidaemic effect of fermented Parkia biglobosa (JACQ) extract in alloxan-induced diabetic rats. Clinical and Experiemntal Pharmacology and Physiology, 33(9), 808-812. https://doi.org/10.1111/j.1440-1681.2006.04444.x

Odunfa, S.A. (1981). Microorganisms associated with fermentation of African locust bean during preparation. Journal of Plant Foods, 3(4), 245-250. https://doi.org/10.1080/0142968X.1981.11904236

Odunfa, S.A. and Oyewole, O.B. (1986). Identification of Bacillus Species from iru, a fermented African locust bean product. Journal of Basic Microbiology, 26(2), 101-108 https://doi.org/10.1002/ jobm.3620260212

Ognatan, K., Adi, K., Lamboni, C., Damorou, J-M., Aklikokou, K.A., Gbeassorand, M., Guilland, J.-C. (2011). Effect of dietary intake of fermented seeds of Parkia biglobosa (Jacq) Benth (African Locust Bean) on hypertension in Bogou and Goumou-kope areas of Togo. Tropical Journal of Pharmaceutical Research, 10(5),603-609. https://doi.org/10.4314/ tjpr.v10i5.9

Otes, S. and Cagindi, O. (2003). Kefir: a probiotic dairycomposition, nutritional and therapeutic aspects. Pakistan Journal of Nutrition, 2(2), 54-59. https:// doi.org/10.3923/pjn.2003.54.59

Park, K.Y., Jeong, J. K., Lee, Y.E. and Daily, J.W. (2014). Health benefits of kimchi (Korean fermented vegetables) as a probiotic food. Journal of Medicinal Foods, 17, 6-20. https://doi.org/10.1089/ jmf.2013.3083

Pẽnas, E., Martinez-Villaluenga, C. and Frias, J. (2017). Chapter 24 - Sauerkraut: Production, composition, and health benefits fermented foods in health and disease prevention, p. 557-576. Boston, USA: Academic Press. https://doi.org/10.1016/B978-0-12802309-9.00024-8

Sanlier, N., G€okcen, B.B. and Sezgin, A.C. (2010). Health benefits of fermented foods. Critical Review in Food Science and Nutrition, 59(3), 506-527. https://doi.org/10.1080/10408398.2017.1383355

Tamang, J.P. and Nikkuni, S. (1996). Selection of starter cultures for the production of kinema, a fermented soybean food of the Himalaya. World Journal of Microbiology and Biotechnology, 12, 629-635. https://doi.org/10.1007/BF00327727

Tamang, J.P., Watanabe, K. and Holzapfel, W.H. (2016). Review: diversity of microorganisms in global fermented foods and beverages. Frontiers in Microbiology, 7, 377. https://doi.org/10.3389/ fmicb.2016.00377

Wang, Y, Xu, N., Xi, A., Ahmed, Z., Zhang, B. and Bai, X. (2009). Effects of Lactobacillus plantarum MA2 isolated from Tibet kefir on lipid metabolism and intestinal microflora of rats fed on high-cholesterol diet. Applied Microbiology Biotechnology, 84, 341347. https://doi.org/10.1007/s00253-009-2012-x

Watanabe, H. (2013). Beneficial biological effects of 
miso with reference toradiation injury, cancer and hypertension. Journal of Toxicologic Pathology, 26 (2), 91-103. https://doi.org/10.1293/tox.26.91

Xiao, J., Huang, G., Zhu, C., Ren, D. and Zhang, S. (2007). Morphological study on apoptosis HeLa cell induced by soyasaponins. Toxicology in Vitro, 21(5), 820-826. https://doi.org/10.1016/j.tiv.2007.01.025 